\title{
MODEL PEMBELAJARAN OPEN ENDED SEBAGAI SOLUSI UNTUK MEMAKSIMALKAN HASIL BELAJAR MATEMATIKA SISWA SD
}

\author{
Evi Wahyu Ningsih ${ }^{1}$, Yudi Budianti ${ }^{2}$, Fanny Sumirat ${ }^{3}$ \\ Universitas Islam “45” Bekasi1, 2, 3 \\ Email: eviwahyuningsihvhizu@gmail.com¹, yudibudianti24@gmail.com², \\ fannysumirat.unisma@gmail.com ${ }^{3}$
}

Submit: 7 Juni 2020, Revisi: 17 Juli 2020, Approve: 11 November 2020

\begin{abstract}
Learning and intruction of mathematic is a process intended for facillitate condition of studentin learning environment atmosphere that will influenced on increasing student achievement in mathematics. Learning outcome problem which happening today on mathematics study in elementary school is focus just one aspect, there is the cognitive aspect. The purpose of the research is to enhance student successfully in mathematics in elementary schools. This research used qualitative and emphasize of data analysis process for comparation conclusion from literature review in several scientific journals. Result of the research find that used the Open Ended Learning model can elevate cognitive aspect in leaning outcomes in mathematics, in other hand can involve all of student to develop their creativity and active in mathematic learning, so that students can feel their confident to built mathematic mind set for answer each of the problems through various strategy. Therefore, this reseach conclude that used Open Ended Learning model as one solution for improve students mathematic learning in elementaryschools.
\end{abstract}

Keywords: Open Ended Model, Learning Outcomes, Mathematics

Pengutipan: Evi Wahyu Ningsih, dkk. (2020). Model Pembelajaran Open Ended sebagai Solusi untuk Memaksimalkan Hasil Belajar Matematika Siswa SD. JMIE: Journal of Madrasah Ibtidaiyah Education, 4(2), 2020, 234-247. jmie.v4i2.192.

Permalink/DOI: http:/ /dx.doi.org/10.32934/jmie.v4i2.192 


\section{PENDAHULUAN}

Perubahan kemajuan ilmu pengetahuan dan teknologi informasi pada saat ini berdampak pada pendidikan, maka isu mengenai pergeseran paradigma pendidikan pun juga turut mengalami perubahan, hal ini akan saling terkait antara konten materi/isi dan pedagogis. Seyogyanya pembelajaran terfokus pada siswa untuk membantu melakukan perubahan konsep dengan proses pembelajaran yang benar. Pembelajaran matematika adalah proses yang dirancang untuk menciptakan suasana lingkungan belajar yang dapat membantu siswa untuk mengembangkan pendekatan saintifik. Menurut Badan Standar Nasional Pendidikan(BSNP) mata pelajaran matematika perlu diberikan kepada semua peserta didik mulai dari Sekolah Dasar (Pebrianti,dkk: 2018). Hal ini dimaksudkan untuk membekali peserta didik dengan kemampuan berpikir logis, analitis, sistematis, kritis dan kreatif, serta kemampuan bekerja sama. Berdasarkan hal tersebut di atas maka dapat diambil suatu pernyataan bahwa proses pembelajaran adalah proses aktualisasi potensi menjadi kompetensi. Standar proses adalah salah satu dari 8 (delapan) SNP (Standar Nasional Pendidikan) yang ditetapkan oleh Pemerintahuntuk dilaksanakan oleh sekolah atau madrasah dalam upayanya mencapai mutu proses pendidikan nasional. Mutu proses pembelajaran di kelas berkorelasi positif dengan mutu hasil pendidikan yaitu kompetensi lulusan. Artinya lebih tingi mutu proses belajar siswa maka lebih tinggi pula hasilnya. Bahkan mutu pendidikan tidak dilihat dari "mutu hasil" melainkan juga "mutu proses". Oleh karena itu, mutu proses pembelajaran yang tinggi akan berdampak pada kecakapan proses berpikir, bersikap dan bertindak dengan mutu yang tinggi pula. Dengan kata lain, kecakapan berpikir siswa akan sangat tergantung pada bagaimana siswa tersebut belajar. Memahami akan hal tersebut maka seharusnya matematika merupakan salah satu pelajaran yang digemari oleh siswa, karena pelajaran matematika memegang peranan penting dalam kehidupan sehari-hari. Sejalan dengan pendapat Japa bahwa pembelajaran matematika adalah proses yang harus direncanakan untuk mengkondisikan siswa dalam kondisi nyaman terhadap lingkungan belajarnya sehingga siswa senang belajar matematika (Cindrayanti, dkk 2012). Lingkungan belajar yang dimaksud yaitu lingkungan belajar non fisik, dimana keadaan psikologis di sekitar siswa yang diciptakan oleh guru secara sengaja untuk mendorong siswa belajar. Adapun, manfaat dari lingkungan belajar non fisik ini, diantaranya yaitu; pertama, membangun hubungan antara guru dengan siswa, yaitu dengan menunjukkan rasa aman pada setiap siswa secara individual melalui dukungan yang terstruktur, penghargaan pada usaha siswa serta yang sedang dikerjakannya dengan mengapresiasi kinerja pencapaian hasil belajarnya selama proses pembelajaran berlangsung di kelas. Kedua, menumbuhkan peningkatan kemandirian, kolaboratif dan motivasi diri. Guru mendukung sepenuhnya agar setiap siswa bertanggungjawab terhadap cara belajar mereka masing-masing, karena keberhasilan pencapaian hasil belajar ada di tangan siswa sendiri, sehingga guru dapat membangun berbagai strategi yang dapat menumbuhkan keterampilan kolaborasi yang produktif. Ketiga, mengembangkan kemampuan berpikir kritis, fleksibel dan 
responsif terhadap tata nilai, serta memahami kebutuhan dan minat siswa secara individual (Sutrisno: 2007). Dengan demikian maka kegiatan dalam pembelajatran matematika tersebut melibatkan siswa aktif untuk membangun kemampuan berpikir, mengemukakan gagasan dan berperan aktif dalam pembelajaran (Azizah,dkk:2016).

Pembelajaran matematika seharusnya disajikan guru dengan menggunakan variasi pendekatan dalam pembelajarannya untuk dapat memfasilitasi siswa dalam memahami konsep matematika, memecahkan masalah dan melatih kemampuan komunikasi matematika sehingga dapat meningkatkan hasil belajar untuk memastikan bahwa siswa mampu mencapai indikator pembelajaran matematika dengan baik, bukan hanya hapalan semata dan menjadikan siswa tidak mau belajar matematika karena dianggap sulit.

Namun kenyataannya pembelajaran matematika yang dilaksanakan saat sekarang ini masih kurang inovatif dan belum menerapkan model pembelajaran yang mampu meningkatkan hasil belajar siswa. Hal ini berpengaruh dikarenakan tiga aspek hasil belajar yaitu aspek kognitif, aspek psikomotor dan aspek afektif harus dikuasai oleh siswa sebagai suatu pencapaian belajar masih rendah dan belum seimbang. Penerapan pembelajaran konvensional yang masih digunakan guru di kelas membuat siswa kurang memiliki kesempatan belajar untuk terlibat dan berperan aktif dalam menyelesaikan persoalan matematika dengan cara menemukannya sendiri bukan mencontoh satu cara yang diberikan oleh guru dan seolah-olah guru membatasi akan kreatifitas siswa (Djampang, dkk: 2019). Adapun rendahnya hasil belajar dapat disebabkan oleh berbagai faktor dan ditengarai ada faktor - faktor lain yang menyebabkan rendahnya kualitas hasil belajar tersebut, antara lain pembelajaran yang kurang inovatif (Sholikah, dkk: 2018), pemilihan model pembelajaran (Koriyah \& Hatta, 2015), dan kompetensi guru serta memilihan materi pembelajaran (Tasirah,dkk: 2016).

Berdasarkan hasil observasi pembelajaran yang telah penulis lakukan sebelumnya di kelas V SD Swasta di kecamatan Bekasi Utara menemukan beberapa kendala yang dialami siswa dalam pembelajaran matematika, diantaranya yaitu sikap siswa yang pasif menandakan bahwa pembelajaran matematika kurang disukai sehingga siswa cenderung hanya mendengarkan saja, diam dan tanpa bertanya meskipun sebenarnya siswa belum memahami materi yang disampaikan oleh guru. Peristiwa seperti ini juga sejalan dengan temuan dari penelitian yang telah dilakukan oleh Setiawan, dkk (2014) hasil penelitiannya menunjukkan bahwa rendahnya minat dan motivasi belajar siswa pada matematika disebabkan kurangnya kemampuan dalam pemecahan masalah sehingga siswa merasa kurang percaya diri yang berdampak kurangnya respon positif dari siswa saat belajar matematika. Hal ini terbukti dari rata-rata nilai UTS semester 1 mata pelajaran matematika adalah 62 dengan ketuntasan siswa $36,36 \%$ dari siswa yang mengikuti pembelajaran dengan $\mathrm{KKM}=68$. Maka dari data yang telah didapat mengindikasikan bahwa hasil belajar matematika siswa masih rendah. Hal ini 
menunjukkan bahwa pembelajaran matematika di sekolah dasar memerlukan model pembelajaran yang aktif, karena akan berdampak pada meningkatnya hasil belajar siswa. Menurut Sabar (2017) menyatakan bahwa jika guru tidak mau berinovasi untuk mengembangkan pembelajaran di kelas maka akan ada kecenderungan prestasi siswa akan tidak berkembang atau rendah. Oleh karena itu, dituntut adanya kesadaran dan kesiapan guru sebagai inovator pembelajaran.

Dalam hal ini maka diperlukan suatu model pembelajaran yang inovatif sebagai langkah awal perbaikan, dikarenakan semakin efektifnya suatu model pembelajaran yang dilaksanakan maka semakin tinggi hasil belajar yang akan diperoleh oleh siswa. Pemilihan materi esensial merupakan faktor penunjang keberhasilan dalam pembelajaran sehingga tujuan pembelajaran dapat tercapai sesuai dengan harapan. Sejalan dengan hal itu Suderadjat (2011) menyatakan bahwa pemilihan dan analisis tema esensial pada materi pelajaran dimaksudkan untuk tercapainya tujuan pembelajaran secara optimal, dengan syarat adanya relevansi tema maupun sub tema dalam materi ajar tersebut berkaitan langsung dengan kehidupan sehari-hari siswa. Dengan demikian sub-sub tema akan menjadi acuan bagi penentuan materi ajar yang akan diberikan pada siswa. Hal ini perlu kita tentukan agar pembelajaran tidak keluar dari konteks tema yang telah kita tentukan, dikarenakan cara berpikir siswa pada usia Sekolah Dasar ini masih berada pada tahap belajar konkret. Siswa belum bisa mengabstraksi terlalu jauh. Selain itu sebagai upaya nyata yang dapat diterapkan untuk membantu dan mengkondisikan siswa belajar dengan nyaman dan menyenangkan pada pembelajaran matematika direkomendasikan ada beberapa pendekatan pembelajaran bagi siswa SD, dimana pendekatan pembelajaran tersebut dapat menciptakan pembelajaran secara aktif kreatif dan menyenangkan bagi siswa dengan difasilitasi oleh guru, salah satunya dengan menggunakan model pembelajaran Open Ended. Model Open Ended ini dapat dijadikan alternatif untuk memaksimalkan tiga aspek hasil belajar pada pembelajaran matematika. Menurut Nohda bahwa tujuan pembelajaran Open Ended yaitu membawa siswa lebih mengembangkan kegiatan kreatif dan pola pikir matematisnya melalui problem solving secara simultan (Setiamiharja, dkk :2017:2). Sedangkan hasil penelitian Nida, dkk (2018) menyatakan bahwa dengan menerapkan model Open Ended akan melatih siswa untuk mempunyai kemampuan berpikir kritis dan kreatif. Kemampuan berpikir kritis yang dikemukakan Marzano, et al (1998) menyatakan bahwa berpikir kritis sebagai berpikir reflektif yang masuk akal yang berfokus pada keputusan untuk yakin dan berbuat yang merupakan wujud tindakan kreatif. Model Open Ended juga di dalam tahapan pelaksanaannya melibatkan siswa dalam proses berpikir untuk memecahkam masalah sehingga model Open Ended termasuk salah satunya model pembelajaran berbasis masalah (Sulastri, dkk : 2015). Hal ini akan terkondisikan pembelajaran yang lebih demokratis, sebab guru dan siswa ada dalam kondisi yang sama, yakni menghadapi masalah, terjadinya proses interaksi antara siswa dalam kelompok maupun antara kelompok siswa serta interaksi yang terjalin dengan guru akan 
terfasilitasi dengan baik. Dengan demikian peran guru dalam pembelajaran adalah sebagai fasilitator, pembimbing dan bahkan moderator pembelajaran sehingga tujuan hasil belajar pada aspek kognitif, psikomotor dan afektif dapat tercapai dengan baik.

Penerapan dalam pelaksanaan pembelajaran dengan menggunakan model Open Ended berdasarkan temuan hasil penelitian Sabar (2017) menunjukkan bahwa guru dengan mudah dapat mengaplikasikan tahapan langkah-langkah model Open Ended dan mendapatkan respon yang positif dalam mengajarkan matematika kepada siswa. Dan hal itu sangat berhubungan dengan adanya upaya menumbuhkan motivasi belajar matematika kepada siswa sehingga pelajaran matematika menjadi mudah, efektif dan menyenangkan.

Jadi, pembelajaran Open Ended dapat dijadikan sebagai salah satu strategi mengajar yang dapat dipilih guru untuk memfasilitasi kegiatan siswa yang aktif dan kreatif. Penelitian relevan lainnya yakni Biliya (2015) melakukan penelitian dan mendapatkan hasil bahwa penerapan model Open Ended dapat mengoptimalkan keterampilan proses dan hasil belajar siswa SD di kelas atas. Adapun penelitian lainnya oleh Hanifah, dkk (2019) hasil penelitiannya menemukan bahwa model pembelajaran Open Ended berbantu media kotak telur pelangi berpengaruh terhadap hasil belajar matematika siswa SD Kanisius Hasanudin Semarang.

\section{METODE PENELITIAN}

Penelitian ini menggunakan metode studi kepustakaan. Kuncoro (2013) menyatakan bahwa tujuan dari tinjauan pustaka yaitu untuk melihat apa saja dan sejauh mana kegiatan yang pernah dilakukan yang berhubungan dengan masalah yang diteliti. Sejalan dengan hal itu Cresswell (2014) berpendapat bahwa literatur review adalah analisis literatur pada sebuah topik penelitian dengan tujuan untuk menginformasikan mengenai hasil penelitian terdahulu yang telah dilakukan yang berkaitan dengan penelitian saat ini yang sedang dikerjakan, menghubungkan sebuah penelitian dengan literatur yang sudah ada, serta mengisi ruang-ruang dalam penelitian sebelumnya.

Langkah-langkah proses penelitian yaitu pertama, menetapkan variabel yang akan dicari literaturnya. Kedua, pengumpulan data atau sumber penelitian. Kegiatan dalam pengumpulan data ini dilakukan dengan menelusuri jurnal relevan yang mendukung pada fokus topik area penelitian yang akan dikaji dari beberapa jurnal ilmiah maupun dari sejumlah buku. Adapun sumber pengumpulan data yang dapat diambil dari beberapa media elektronik seperti internet, jurnal online, perpustakaan online serta buku. Ketiga, analisis data. Kegiatan analisis data ini melibatkan beberapa tahapan, diantaranya yakni dengan cara mencatat seluruh penulis dan judul dari artikel hasil penelusuran, memeriksa kembali dan mencocokkan artikel yang telah terkumpul, dan membuat resume untuk memilih hal-hal yang pokok serta memfokuskan pada hal-hal yang penting. Selanjutnya, yaitu penyajian data, pada 
tahapan ini dalam rangka memudahkan peneliti untuk memeriksa hasil penelusuran maka dibuat matriks yang berisikan hubungan antar kategori pada topik area penelitian yang relevan, yakni membuat gambaran dari sumber pustaka dengan menuliskan penulis, tahun publikasi, ide utama dan abstrak. Tahapan terakhir dari analisis data yaitu penarikan kesimpulan dan verifikasi data sebagai proses kegiatan dalam menemukan hal baru yang sebelumnya belum pernah ada. Keempat,; mengembangkan ide dan mendemontrasikan pengetahuan untuk menghasilkan sebuah gagasan yang akan dituangkan dan disajikan ke dalam tulisan.

\section{HASIL DAN PEMBAHASAN}

\section{Isu utama dalam pembelajaran matematika di Sekolah Dasar}

Ada tiga isu utama terkait kesulitan yang dialami oleh siswa Sekolah Dasar dalam mempelajari matematika, yaitu memahami konsep, memecahkan masalah dan komunikasi matematis. Isu pertama adalah rendahnya pemahaman konsep siswa dalam pembelajaran matematika. Sulitnya belajar matematika sering dikeluhkan oleh para siswa, tidak terkecuali siswa SD. Hal ini terjadi mungkin dikarenakan faktor pemilihan model pembelajaran matematika sebagai strategi agar siswa dapat mengembangkan aspek kognitifnya belum tepat diterapkan di kelas. Hal ini sejalan dengan Nabila (2019) mendapati bahwa faktor penyebab rendahnya hasil belajar dikarenakan oleh berbagai macam faktor, salah satunya adalah model pembelajaran yang kurang menyenangkan, sedangkan siswa diwajibkan bisa berfikir kreatif, imajinatif dan keinginan belajar yang tinggi. Dampak persepsi yang ditimbulkan oleh siswa menjadi pembelajaran matematika yang terkesan kaku, tidak menarik dan banyaknya rumus yang harus dihafal. Hal tersebut akan membuat siswa menjadi kurang tertarik mengikuti pembelajaran matematika dan akan berdampak pada rendahnya hasil belajar siswa. Isu kedua, kurangnya berlatih dalam menyelesaikan soal-soal pemecahan masalah matematika yang dihubungkan dengan kehidupan sehari-hari. Ngatifah (2014) menyatakan bahwa matematika adalah pelajaran yang akan bermanfaat bagi kehidupan sehari-hari dimana kita akan menjumpai penjumlahan dan pengurangan serta pembagian hingga perkalian yang menggunakan berbagai macam rumus. Maka dari itu dibutuhkan latihan yang menyenangkan dan pedoman untuk mempelajarinya, bukannya semata-mata hafalan. Sejalan dengan hal itu, Pintauli (2019) menyebutkan pentingnya kemampuan pemecahan masalah untuk kehidupan sehari-hari harus dibelajarkan kepada siswa dalam mata pelajaran matematika disekolah. Mengapa hal itu sangat penting? Dikarenakan tujuannya untuk membekali para siswa memiliki kemampuan untuk menyelesaikan masalah yang akan dihadapinya di masa yang akan datang. Isu ketiga, kurangnya interaksi para siswa dalam pembelajaran matematika menyebabkan komunikasi matematisnya tidak berkembang. Penugasan yang diberikan guru menuntut siswa belajar secara individu dengan mengerjakan soal-soal latihan dari buku paket 
atau lembar kerja siswa. Sutarna (2016) berpendapat bahwa kurang tepat jika guru menggunakan model penugasan dalam pembelajaran matematika di SD walaupun tujuannya untuk melatih siswa, dengan alasan pelajaran matematika memiliki berbagai macam rumus dan cara penyelesaian masalah, yang mana diperlukan adanya bimbingan serta latihan di dalam proses pembelajarannya.

Hal ini mungkin disebabkan oleh kurang efektifnya penerapan model pembelajaran matematika yang dilaksanakan oleh guru-guru terutama di Sekolah Dasar. Peningkatan tiga aspek hasil belajar siswa dapat dilakukan dengan optimalisasi kesesuaian model pembelajaran matematika yang tepat, karena akan memberikan dampak pada hasil belajar siswa. Hasil belajar merupakan kemampuan siswa dalam kegiatan belajar disekolah yang dapat diukur dengan berbagai model pembelajaran dan juga guru dapat mengetahui sejauh mana siswa dalam memecahkan permasalahan matematika (Nurdeni, dkk: 2010). Setiamiharja, dkk (2007) berpendapat bahwa pembelajaran matematika di Sekolah Dasar dengan memilih dan menggunakan pendekatan model Open-Ended adalah sudah tepat, mengingat pada umumnya siswa SD aktif sehingga dapat menumbuhkan minat dengan pembelajaran yang interaktif saling bekerjasama dalam mengerjakan soal. Oleh karena itu, model pembelajaran ini merupakan rujukan untuk mata pelajaran matematika khususnya di Sekolah Dasar sebagai model yang pas untuk digunakan. Di mana siswa dapat belajar sambil bermain memecahkan kasus - kasus atau soal-soal yang diberikan oleh guru (Pintauli, 2019).

\section{Model pembelajaran Open Ended sebagai solusi dalam pembelajaran matematika}

Penerapan pembelajaran dengan menggunakan model pembelajaran Open Ended mampu melibatkan siswa lebih paham dalam menyikapi masalah atau soal-soal yang diberikan oleh guru. Model Open Ended juga merupakan suatu pembelajaran yang dapat mengasah kekompakan siswa dalam menginvestigasi berbagai strategi dan macam-macam cara yang mereka yakini sesuai dengan kemampuan tim dalam kelompoknya untuk mencari pemecahan masalahnya. Pencapaian hasil belajar mengacu pada aspek pengetahuan, aspek keterampilan dan aspek sikap yang akan dijabarkan dalam tujuan dan indikator pembelajaran secara menyeluruh. Dalam hal ini penulis mencoba untuk menjabarkan ketiga aspek hasil belajar tersebut yang terdapat dalam model pembelajaran Open Ended dengan menganalisis pada setiap tahapannya. Adapun model pembelajaran Open-Endedini memiliki empat tahapan, yaitu tahapan perencanaan, tahapan pelaksanaan, tahapan penilaian dan tahapan refleksi. Lestari, dkk (2017) menjabarkan tahapan model Open-Ended sebagai berikut: Tahapan perencanaan, dalam tahapan ini terdapat beberapa kegiatan diantaranya yaitu menganalisa materi pembelajaran matematika serta indikator; menyiapkan RPP sesuai indikator; membuat rancangan tes uraian dan LKS; membuat instrumen observasi untuk mengamati dan menilai kegiatan belajar mengajar. Dalam pembelajaran tahapan perencaan merupakan bagian yang 
penting disebabkan akan menjadi pedoman antara guru dan siswa di kelas. Hal ini diperuntukkan untuk memfasilitasi sebuah pengetahuan baru yang akan diperoleh siswa selama belajar. Menurut Brooks \& Dansereau (1987) menyatakan bahwa belajar dan mengajar pada prinsipnya merupakan kegiatan untuk memfasilitasi transfer ilmu pengetahuan dan keterampilan sehingga membutuhkan strategi dalam perencanaan pembelajaran yang beragam. Guru merancang dan mengimplementasikan suatu kegiatan yang menumbuhkan belajar yang berkelanjutan, melalui penekanan hubungan antar gagasan dan konsep, serta menumbuhkan keterampilan investigasi dan penyelesaian masalah. Rencana pembelajaran merupakan rencana yang disusun oleh guru untuk satu atau dua kali pertemuan tatap muka dengan tujuan untuk mencapai target satu kompetensi dasar. Dalam rencana pemebalajaran juga berisi gambaran tentang kompetensi dasar yang akan dicapai, indikator, materi pokok, skenario pembelajaran yang dijabarkan tahap demi tahap serta penilaiannya (Sutrisno, dkk: 2007). Menyusun rencana pembelajaran bukan hal yang mudah bagi guru, dikarenakan hal ini memerlukan pertimbangan atas berbagai faktor yang harus dipertanggungjawabkan sehingga keterampilan dalam mengambil suatu keputusan merupakan hal yang sangat penting dimiliki oleh guru (Zendrato: 2016). Komitmen yang dipegang oleh seorang guru dalam melaksanakan tugasnya di sekolah merupakan bentuk profesionalisme (Jannah: 2014). Tahapan pelaksanaan, pada tahapan ini terdapat empat langkah. Pertama, langkah OpenEnded Problems, pada langkah ini siswa diberikan suatu masalah yang terdapat dalam kehidupan sehari-hari dan memiliki penyelesaian jawaban lebih dari satu jawaban. Dalam tahapan ini siswa dituntut untuk memiliki kemampuan berpikir dalam pemahaman konsep dasar matematika sehingga bisa meyelesaikan persoalan yang disajikan. Menurut Dahar (1985) keefektifan pengajaran dalam suatu kelas haruslah berkaitan dengan suatu peristiwa dalam kehidupan sehari-hari dimana dengan hal itu siswa dapat memandang suatu masalah yang nyata. Adapun hasil penelitian Djampamg, dkk (2014) menemukan bahwa ketidaknyamana siswa dalam pelaksanaan belajar matematika berdampak pada kurangnya pemahaman materi lebih mendalam yang berdampak pada siswa dimana siswa hanya mampu menyelesaikan satu cara penyelesaian soal matematika untuk jawabannya yang dicontohkan oleh guru tanpa mau mencari jawaban dengan cara penyelesaian soal matematika yang lain. Oleh karena itu dalam tahapan pelaksanaan pembelajaran ini guru harus memikirkan bagaimana memilih dan mengambil strategi yang tepat. Kedua, langkah Contructivism, pada langkah ini siswa menemukan pola untuk mengkontruksi permasalahan sendiri. Pandangan kontruktivisme mensyaratkan bahwa pembentukan pengetahuan didasarkan dari pemahaman siswa terhadap suatu peristiwa/fenomena yang dipengaruhi oleh informasi baru yang didapatkannya (Sumirat, 2012). Dalam tahapan ini siswa dapat meningkatkan kreativitas dan pemecahan masalah nyata yang dihadapi dengan tindakan yang etis dan cerdas. Untuk memiliki kemampuan tersebut Ennis (1991) menyatakan bahwa seseorang yang mempunyai daya menalar yang baik dapat menentukan pada apa yang diyakini dan dilakukannya. Ketiga, 
langkah exploration, pada langkah ini siswa menyelesaikan masalah dengan banyak cara penyelesaian melalui kegiatan eksplorasi. Dalam tahapan ini siswa mampu mencari solusi yang bersumber dari penggunaaan proses pemecahan masalah, berpikir rasional dan mengambil suatu keputusan. Proses eksplorasi ini ditandai dengan mengumpulkan dan mengorganisasikan informasi yang didapat. Berdasarkan hasil penelitian Rahman \& Ahmar (2016) menyatakan bahwa proses eksplorasi dalam memecahkan masalah matematika tergantung dari tingkatan perkembangan kogtitifnya. Dikarenakan tahapan perkembangan kognitif setiap orang berbeda levelnya maka akan berpengaruh juga pada bagaimana seseorang itu mengeksplorasi dalam menyelesaikan masalahnya. Untuk tahapan ini, Piaget (1965) membagi tahapan perkembangan kognitif menjadi empat tahapan yaitu, tahapan sensorimotor (0-2 tahun), tahapan pra-operasional (2-7 tahun), tahapan operasional konkrit (7-11 tahun), dan tahapan operasional formal (11 tahun ke atas). Dalam tahapan perkembangan kognitifnya siswa SD berada pada tahapan operasional konkrit dimana anak dapat bernalar secara logis mengenai hal-hal yang konkrit atau spesifik, dan anak sudah dapat membentuk pengetahuannya sendiri. Menurut Imai (2010) menyatakan bahwa proses pemecahan masalah dalam matematika dibangun dalam bentuk elaborasi keterampilan berpikir dan kreativitas sehingga siswa mampu memecahkan maslah dengan gagasan yang baru. Keempat, langkah Presentation, pada langkah ini siswa menyajikan hasil temuannya. Dalam tahapan ini siswa berlatih untuk memampukan diri dalam komunikasi matematika baik secara lisan maupun tulisan yang didasari dari kemampuan berpikir dan bertindak. Bardasarkan temuan dari hasil penelitian Astuti \& Leonard (2012) menyatakan bahwa kemampuan komunikasi matematika dapat dilatihkan sehingga adanya peningkatan yang signifikan terhadap hasil belajar siswa dalam pembelajaran matematika. Untuk mengukur kemampuan komunikasi matematika terdapat tiga indikator, yakni : mampu memvisualisasikan gambar yang didasarkan dari hasil kemampuan menjelaskan masalah matematika, mengemukakan gagasan dengan menggunakan bahasa sendiri berdasarkan dari hasil analisis masalah matematika dan dapat menuliskan simbol serta melakukan perhitungan dalam mencari solusi penyelesaian masalah yang dihadapi (Sari: 2017).

Selanjutnya yaitu tahapan penilaian, pada tahap penilaian menggunakan instrumen tes uraian karena bertujuan untuk memperoleh data-data hasil belajar siswa setelah menggunakan model Open-Ended, menganalisa data dan melakukan wawancara kepada guru. Penilaian yang dimaksudkan merupakan serangkaian kegiatan untuk memperoleh, menganalisis,dan menafsirkan data tentang proses dan hasil belajarsiswa yang dilakukan secara sistematis, berkesinambungan, sehingga hal tersebut menjadi suatu informasi bermakna yang dapat dipergunakan untuk mengambil keputusan. Penguasaaan sejumlah pengetahuan, keterampilan dan sikap yang telah ditetapkan berdasarkan indikator dapat diukur di akhir pembelajaran sebagai bukti bahwa tujuan pembelajaran telah tercapai atau tidak. Keefektifan sebuah perangkat penilaian tergantung dari mudahnya penilaian itu dapat 
diukur, menurut Nuriyah (2014) bahwa penilaian dapat diklasifikasikan menurut kategori tertentu. Pada umumnya untuk merujuk pada sebuah pengelompokkan kategori secara spesifik dapat dipilih seperti Taksonomi Bloom yang membagi hasil belajar kedalam tiga aspek yaitu aspek kognitif, aspek psikomotor dan aspek afektif. Berdasarkan pendapat Sudjana (2009) bahwa ranah kognitif berkenaan dengan hasil belajar intelektual, ranah psikomotor berkenaan dengan hasil belajar keterampilan dan kemampuan bertindak, dan ranah afektif berkenaan dengan sikap. Kelebihan dan kekurangan siswa dari tiga aspek hasil belajar tersebut dapat terukur secara komprehensif melalui sebuah proses penilaian (Kunaini: 2017). Penilaian diarahkan untuk mengukur pencapaian kompetensi dasar, dan menggunakan acuan kriteria yaitu berdasarkan atas apa yang bisa dilakukan siswa setelah mengikuti proses pembelajaran, dan bukan untuk menentukan posisi seorang siswa terhadap kelompoknya, selanjutnya hasil penilaian dianalisis untuk menentukan tindak lanjut, yakni berupa perbaikan proses pembelajaran pada kegiatan pelaksanaan pembelajaran berikutnya, program remedial bagi siswa yang pencapaian kompetensinya berada dibawah kriteria ketuntasan, dan program pengayaan bagi siswa yang telah memenuhi kriteria ketuntasan (Suderadjat: 2011). Menurut pendapat Salamah (2018) menyatakan bahwa penilaian berkaitan dengan penjaminan mutu suatu lembaga pendidikan. Oleh karena itu dalam tahapan penilaian ini harus memenuhi standar kriteria BSNP, sehingga dapat dipertanggungjawabkan pada masyarakat. Dengan demikian, untuk upaya peningkatan pemahaman guru dalam hal penilaian pembelajaran, maka Setiadi (2016) menyarankan guru harus diberikan pelatihan berkala mengenai teknik penilaian, diberikan bimbingan dalam menganalisis instrumen penilaian dan revisi pada butir soal. Tahapan refleksi, dalam langkah refleksi, data yang diperoleh dari hasil pengamatan kemudian di analisis berdasarkan pengamatan terhadap proses pembelajaran karena bertujuan untuk mengetahui sejauh mana efektivitas pelaksanaan pembelajaran matematika dengan menggunakan model Open-Ended. Optimalisasi pada tahapan ini yakni sebuah evaluasi yang bisa memberikan masukan dan saran mulai dari penilaian masukan, proses maupun luaran dari aktifitas pembelajaran yang telah dilakukan. Hal ini dimaksudkan untuk adanya perbaikan kualitas guru dan hasil belajar siswa (Mahirah: 2017).

Berdasarkan hal tersebut diatas maka salah satu tugas guru dalam proses pembelajaran matematika adalah membantu memfasilitasi para siswa belajar dengan suasana yang menyenangkan, Ikmah \& dkk (2018) merekomendasikan bahwa model pembelajaran Open-Ended cocok untuk pembelajaran matematika di SD, dikarenakan model tersebut dapat mendorong siswa untuk bereksplorasi dan berkolaborasi dalam memecahkan masalah bersama-masa, sehingga siswa penuh motivasi, lebih ceria dan menyenagkan serta hasil belajar siswa pun memiliki perubahan kearah yang lebih baik. 


\section{SIMPULAN}

Penelitian ini menganalisis kesulitan-kesulitan yang dihadapi siswa Sekolah Dasar dalam pembelajaran matematika. Hasil penelitian menunjukkan bahwa terdapat tiga isu utama yaitu memahami konsep, memecahkan masalah dan komunikasi matematis. Pembelajaran matematika masih dianggap sebagai pelajaran yang sulit bagi siswa SD, hal itu dimungkinkan guru yang mengajar di Sekolah Dasar kurang efektif menerapkan model pembelajaran matematika yang bervariasi. Kurangnya sosialisasi dan pelatihan mengenai model pembelajaran matematika kepada guru-guru diduga sebagai salah satu faktor penyebabnya. Temuan ini dapat dijadikan bahan pertimbangan bagi pihak sekolah maupun pemerintah dalam meningkatkan hasil belajar matematika yang lebih baik di SD. Model pembelajaran Open-Ended merupakan model pembelajaran yang tepat digunakan dalam pembelajaran matematika di SD sehingga dapat dipilih untuk dijadikan alternatif dalam memaksimalkan tiga aspek hasil belajar yaitu aspek kognitif, aspek psikomotor dan aspek afektif dalam pembelajaran matematika, selain itu dapat sepenuhnya melibatkan siswa untuk mengembangkan kegiatan kreatif dan aktif dalam pembelajaran sehingga pelajaran matematika lebih akan lebih menyenangkan.

\section{DAFTAR PUSTAKA}

Astuti, A., \& Leonard. (2012). Peran Kemampuan Komunikasi Matematika Terhadap Prestasi Belajar Matematika Siswa. Jurnal Ilmiah Pendidikan MIP A, Vol. 2, No.2.

Azizah, N., Suhartono, \& Suryandari, K. C. (2016) Peningkatan Kemandirian Dan Hasil Belajar Matematika Melalui Model Open Ended Learning dengan Media Muatan di Kelas IV SDN 3 Tamanwinangun. Kalam Cendekia, Vol 4 No 4.1, 427-433.

Belliya, B.A. (2015). Penerapan Model Open Ended UntukMeningkatkanKeterampilan Proses Dan HasilBelajarSiswaKelas V SDN 1 RepakingWonosegoroBoyolali. JurnalScholaria, Vol. 5 No. 1, 78-91.

Brooks, L., \& Dansereau, D. (1987). Transfer of Learning. Chapte 5- Transfer of information: An instructional Persfective. Academic Press.

Cidrayanti, L. P., Suwatra, I. I., \& Sumantri, M. (2016). Pengaruh Pendekatan Open Ended Terhadap Hasil Belajar Matematika Siswa Kelas IV Di Gugus III Kabupaten Bangli. eJournal PGSD Universitas Ganesha, Vol 4 No 1, 1-10.

Creswell, J. (2014). Penelitian Kualitatif dan Desain Riset. Yogyakarta: Pustaka Belajar.

Dahar, R. (1985). Kesiapan Guru Mengajar Sains di SD Ditinjau dari Segi Pengembangan Keterampilan Proses. Disertasi IKIP Bandung: tidak diterbitkan 
Djampang, S., Ilyas, M., \& Basir, F. (2019). Efektifitas Model Problems Based Learning Dengan Pendekatan Open Ended Untuk Meningkatkan Hasil Belajar Matematika Siswa Kelas VII SMPN 3 Bajo. Jurnal Penelitian Matematika dan Pendidikan Matematika.

Ennis, R. (1991). 'Critical Thinking: A Streamlined Conception”. Journal Teaching Philosophy, 14 (1). 5-24.

Hanifah, N. M., Kh. B, M. A., \&Budiman, M. A. (2019). Pengaruh Model Open Ended Problem Berbantu Media Kotak Telur Pelangi (KOTELA) Terhadap Hasil Belajar Matematika. Journal of Technology, Vol. 3 No. 3, 134-139.

Ikmah, F., Maryadi, \& Wijayanti, A. (2018). Pengaruh Model Pembelajaran Open Ended Problem Berbantu Media Kalkulator Dakon (Kakon) Terhadap Hasil Belajar Matematika Kelas II SDN Sambiroto 01 Kec.Tembalang Kota Semarang. Jurnal Guru Kita (JKG), Vol 2 No 3, 126-133.

Imai, T. (2010). The Influence of Overcoming Fixation in Mathematics Towards Divergent Thinking in Open-Ended Mathematics Problems on Japanese Junior High School Students. International Journal of Mathematical Education, 1(2):187-193.

Jannah, W. (2014). Komitmen Guru dalam Melaksanakan Tugas di Sekolah Menengah Atas Kecamatan Rokan IV Koto. Bahana Manajemen Pendidikan. Jurnal Administrasi Pendidikan, Vol. 2 Nomor 1, Ha. 732-831.

Kunaini, A. (2017). Penilaian Pembelajaran Tematik di Madrasah. Jurnal Pedagogik, Vol. 4, No, 2.

Kuncoro, M. (2013). Metode Riset untuk Bisnis dan Ekonomi. Edisi 3. Jakarta: Erlangga..

Lestari, K. D., Suniasih, N. W., \& Manuaba, L. S. (2017). Pengaruh Model Pembelajaran Open Ended Berbasis Keterampilan Menjelaskan Terhadap Kompetensi Pengetahuan IPA. Journal Of Education Technology, Vol 1 No 3, 169-175.

Koriyah, V.N., \& Hatta, I (2015). Pengaruh Open Ended terhadap Prestasi Belajar, Berpikir Kritis dan Kepercayaan Diri Siswa SMP. Jurnal Pendidikan Matematika, Vol. 10 no. 1, 95105.

Marzano, et al. (1998). "Dimension of Thinking: A Framework for Curriculumand Instruction". Virginia: Assosiation for Supervision and Curriculum Development.

Mahirah, B. (2017). Evaluasi Belajar peserta Didik. Jurnal Idaraah, Vol. 1 No. 2.

Nabilah, T., Abadi, A. P. (2019). Faktor Penyebab Rendahnya Hasil Belajar Siswa. Prosiding Seminar Nasional Matematika dan Pendidikan Matematika. 1-7.

Nada, I., Utaminingsih, S., \& Ardianti, S. D. (2018). Penerapan Model Open Ended Problems 
Evi Wahyu Ningsih, dkk

Berbantuan CD Pembelajaran untuk Meningkatkan Kemampuan Berpikir Kreatif Siswa Kelas IV SD 1 Golantepus. JPSD , Vol. 4 No. 2, 12

Ngafifah, N., Budi, H. S., \& Warsiti. (2014). Penggunaan Model Open Ended Learning Untuk Meningkatkan Pembelajaran Matematika Siswa Kleas IV Sekolah Dasar.1-5.

Nurdeni, \& Ariyani, K.( 2010). Peningkatan Hasil Belajar Matematika Dalam Menyelesaikan Soal Bilangan Perkalian Dan Pembagian Di Kelas II SD. Jurnal Formatif, No 3, 255-263.

Nuriyah, N. (2014). Evaluasi Pembelajaran: Sebuah Kajian Teori. Jurnal Edueksos, Vol.3, No. 1.

Pebrianti, A. P., Sumardi, \&Pranata, O. H. (2018). Penerapan Cooperative Learning Tipehink Pair Share Untuk Meningkatkan Hasil Belajar Siswa tentang Penjumlahan Pecahan Berpenyebut Beda. JurnallmiabPendidikan Guru SekolabDasar, Vol. 5 No. 1, 23-31

Pintauli, S. (2019). Kemampuan Pemecahan Masalah Matematika Melalui Model- Model Pembelajaran. Jurnal Pendidikan Matematika , 1-6.

Sabar, M. N. (2017). Effectiveness of Problems Based Learning Model (PBL) Setting Open Ended Approach Mathematics Learning. Jurnal Daya Matematis, Volume 5 No. 3, 9.

Rahman, a \& Ahmar, A. (2016). Exploration of Mathematics Problem Solving Process Based on The Thinking Level of Students in Junior High School. International Journal of Enviromental and Science Education, Vol. 11, No.14.

Salamah, U. (2018). Penjaminan Mutu Penilaian Pendidikan. Evaluasi, Vol. 2, No. 1.

Sari, M. (2017). Analysis of Student's Mathematical Communication Ability by Using Cooperative Learning Talking Stick Type. STKIP Siliwangi Journals, Vol. 6, No. 2.

Setiawan, R. H., \& Harta, I. (2014). Pengaruh Pendekatan Open Ended dan Pendekatan Kontekstual Terhadap Kemampuan Pemecahan Masalah dan Sikap Siswa terhadap Matematika. Jurnal Riset Pendidikan Matematika, Vol. 1 No. 2, 17.

Setiadi, H. (2017). Pelaksanaan Penilaian Pada Kurikulum 2013. Jurnal Penelitian dan Evaluasi Pendidikan Vol.20, No 2.

Setiamihardja, R., \& Kusmiyati. (2007). Pendekatan Open Ended Dalam Pembelajaran Matematika Di Sekolah Dasar. Jurnal Pendidikan Dasar, No 8, 1-5.

Suderadjat, H. (2011). Manajemen Pembelajaran Tematik. Bandung: Sekar Gambir Asri.

Sudjana, N. (2009). Penilaian Hasil Proses Belajar Mengajar. Bandung: PT Remaja Rosda Karya.

Sulastri, Imran, \& Firmansyah, A. (2015). Meningkatkan Hasil Belajar Siswa Melalui Strategi Pembelajaran Berbasis Masalah Pada Mata Pelajaran IPS di Kelas VSDN 1 Limbo Makmur Kecamatan Bumi Raya. Jurnal Kreatif Tadulako Online, Vol. 3 No. 1. 
Sutrisno, L. dkk,. (2007). Pengembangan Pembelajaran IPA. Direktorat Jenderal Pendidikan Tinggi Departemen Pendidikan Nasional.

Sholikha, Z., Kartana, T.J, \& Utami, W.B. (2018) Efektifitas Model Pembelajaran Open Ended Terhadap Prestasi Belajar Matematika Ditinjau dari Kreatifitas Siswa. JES-MAT, Vol.4 No. 1, 1-2.

Sumirat, F. (2012). Efektivitas Model Pembelajaran Predict-Observe-Explain (POE) untuk Meningkatkan Keterampilan Berpikir Kritis dan Memfasilitasi Perubahan Konseptual Siswa dalam Pembelajaran IPA. Tesis: UPI Bandung

Sutarna, N. (2016). Penerapan Metode Penugasan Untuk Meningkatkan Kemampuan Memahami Peta Pada Siswa Sekolah Dasar. Jurnal Pendidikan Geografi, Vol 16 No 1, 2433.

Tasirah, dkk. (2016). Penggunaan Model Open Ended Learning Dengan Multimedia untuk Meningkatkan Pembelajaran Bangun Ruang Siswa Kelas V SD Negeri 3 Panjer. Kalam Cendekia, Vol. 4 No. 2.1, 122-127.

Zendrato, J. (2016). Tingkat Penerapan Rencana Pelaksanaan Pembelajaran dalam Pelaksanaan Pembelajaran di Kelas. Scholaria Jurnal Pendidikan dan kebudayaan 6(2): 58. 